\title{
Two new xanthones and cytotoxicity from the bark of Garcinia schomburgkiana
}

\author{
Sutin Kaennakam ${ }^{1} \cdot$ Kamonwan Mudsing $^{1} \cdot$ Kitiya Rassamee $^{2} \cdot$ Pongpun Siripong $^{2} \cdot$ Santi Tip-pyang $^{1}$
}

Received: 25 May 2018 / Accepted: 17 August 2018 / Published online: 31 August 2018

(c) The Author(s) 2018

\begin{abstract}
Two new xanthone derivatives, named schomburgones A (1) and B (2), along with eight known compounds, including xanthones (3-8) and anthraquinones (9-10) were isolated from the bark of Garcinia schomburgkiana. Their structures were determined by spectroscopic analysis especially 1D and 2D NMR spectroscopies. All isolated compounds were evaluated for their cytotoxicity against five cancer cell lines (KB, HeLa S-3, HT-29, MCF-7 and HepG-2). Compounds 3-6 and 8 showed good cytotoxicity against all the five cancer cell lines with $\mathrm{IC}_{50}$ values in the range of $1.45-9.46 \mu \mathrm{M}$.
\end{abstract}

Keywords Garcinia schomburgkiana $\cdot$ Clusiaceae $\cdot$ Xanthone $\cdot$ Cytotoxicity

\section{Introduction}

Garcinia schomburgkiana Pierre (family Clusiaceae) is a medium-sized tree distributed in Thailand, Laos, Vietnam, and Cambodia. In folk medicine in these countries, its leaves, roots, and fruits are used for the treatment of cough, menstrual disturbances, expectorant, laxative and diabetes [1]. Previous chemical and biological studies on the chemical constituents of G. schomburgkiana showed the presence of xanthones, depsidones, biphenyls, flavonoids, triterpenoids, and phloroglucinols, some of which exhibited antimalarial activity and cytotoxicity [2], [3]. Here, we reported two new xanthone derivatives, named schomburgones A (1) and B (2), along with six known xanthones (3-8) and two known anthraquinones (9-10) from the bark of this plant. The structures of all isolated compounds were elucidated

Electronic supplementary material The online version of this article (https://doi.org/10.1007/s11418-018-1240-8) contains supplementary material, which is available to authorized users.

Sutin Kaennakam

n-s-k-@hotmail.com

Santi Tip-pyang

santi.Ti@chula.ac.th

1 Center of Excellence in Natural Products Chemistry, Department of Chemistry, Faculty of Science, Chulalongkorn University, Bangkok 10330, Thailand

2 Natural Products Research Section, Research Division, National Cancer Institute, Bangkok 10400, Thailand using spectroscopic methods especially $1 \mathrm{D}$ and 2D NMR spectroscopies and compared with their ${ }^{1} \mathrm{H}$ and ${ }^{13} \mathrm{C}$ NMR spectroscopic data from the literature. The cytotoxicity of all isolated compounds was evaluated using the MTT method against five cancer cell lines.

\section{Results and discussion}

Phytochemical investigation of $\mathrm{CH}_{2} \mathrm{Cl}_{2}$ crude extract from the bark of $G$. schomburgkiana led to the isolation of two new xanthone derivatives, named schomburgones A (1) and B (2), along with eight known compounds (Fig. 1), including isocudraniaxanthone B (3) [4], gerontoxanthone I (4) [5], nigrolineaxanthone E (5) [6], isojacareubin (6) [7], dulxanthone A (7) [8], macluraxanthone (8) [9], vismiaquinone A (9) [10], and 3-geranylemodin (10) [11]. The structures of all isolated compounds were elucidated using spectroscopic methods especially NMR spectroscopies and compared with their ${ }^{1} \mathrm{H}$ and ${ }^{13} \mathrm{C}$ NMR spectroscopic data from the literature.

Schomburgone A (1) was obtained as yellow oil. Its molecular formula was determined as $\mathrm{C}_{24} \mathrm{H}_{24} \mathrm{O}_{6}$ by the negative HRESIMS measurement through the ion peak at $m / z$ 407.1527 [M-H] ${ }^{+}$(calcd. for $\mathrm{C}_{24} \mathrm{H}_{23} \mathrm{O}_{6}, 407.1495$ ). The UV spectrum displayed absorption bands at $\lambda_{\max } 395$, 315 and $243 \mathrm{~nm}$, which is typical of the xanthone chromophore [12]. The IR spectrum showed phenolic hydroxyl groups and a hydrogen bonded carbonyl group at 3422 and $1632 \mathrm{~cm}^{-1}$. The ${ }^{1} \mathrm{H}$ NMR spectrum showed the presence 
<smiles>COc1cc(O)c2c(=O)c3c4c(c(O)cc3oc2c1CC=C(C)C)OC([13CH3])([14CH3])C=[C+]4</smiles><smiles>C=CC(C)(C)c1c(OC)cc(O)c2c(=O)c3cccc(O)c3oc12</smiles><smiles>C=CC(C)(C)c1c(OC)cc(O)c2c(=O)c3ccc(O)c(O)c3oc12</smiles><smiles>C=CC(C)(C)c1c(O)cc(O)c2c(=O)c3ccc(O)c(O)c3oc12</smiles><smiles>C=CC(C)(C)c1c(OC)c(CC=C(C)C)c(O)c2c(=O)c3ccc(O)c(O)c3oc12</smiles><smiles>CC1(C)C=Cc2c(cc(O)c3c(=O)c4ccc(O)c(O)c4oc23)O1</smiles><smiles>COc1cc(O)c2c(=O)c3ccc(O)c(O)c3oc2c1CC=C(C)C</smiles><smiles>C=CC(C)(C)c1c2c(c(O)c3c(=O)c4ccc(O)c(O)c4oc13)C=CC(C)(C)O2</smiles><smiles>COc1cc2c(c(O)c1/C=C/C(C)C)C(=O)c1c(O)cc(C)cc1C2=O</smiles><smiles>CC(C)=CCC/C(C)=C/COc1cc(O)c2c(c1)C(=O)c1cc(C)cc(O)c1C2=O</smiles>

10

Fig. 1 Chemical structures of 1-10

of a 3,3-dimethylallyl substituent, which was confirmed by two singlets at $\delta_{\mathrm{H}} 1.67\left(3 \mathrm{H}, \mathrm{s}, \mathrm{H}-4^{\prime}\right)$ and $1.85\left(3 \mathrm{H}, \mathrm{s}, \mathrm{H}-5^{\prime}\right)$ for the vinyl methyls, a triplet at $\delta_{\mathrm{H}} 5.20(1 \mathrm{H}, \mathrm{t}, J=7.23 \mathrm{~Hz}$, $\left.\mathrm{H}-2^{\prime}\right)$ for the vinylic proton and a doublet at $\delta_{\mathrm{H}} 3.44(2 \mathrm{H}, \mathrm{d}$, $J=7.23 \mathrm{~Hz}, \mathrm{H}-1^{\prime}$ ) for the allylic proton of prenyl group. In addition, the methoxy signal, a hydroxyl signal, two aromatic proton signals and a hydrogen bonded hydroxyl signal appeared as five singlets at $\delta_{\mathrm{H}} 3.89\left(3 \mathrm{H}, \mathrm{s}, \mathrm{OCH}_{3}-3\right), 6.26$ $(1 \mathrm{H}, \mathrm{s}, \mathrm{OH}-6), 6.33(1 \mathrm{H}, \mathrm{s}, \mathrm{H}-2), 6.85(1 \mathrm{H}, \mathrm{s}, \mathrm{H}-5)$ and 13.38 $(1 \mathrm{H}, \mathrm{s}, \mathrm{OH}-1)$, respectively. The signals at $\delta_{\mathrm{H}} 1.50(6 \mathrm{H}, \mathrm{s}$, $\mathrm{H}-4 "$ and $\mathrm{H}-5 "), 5.83\left(1 \mathrm{H}, \mathrm{d}, J=10.23 \mathrm{~Hz}, \mathrm{H}-2^{\prime \prime}\right)$ and 8.02 $\left(1 \mathrm{H}, \mathrm{d}, J=10.23 \mathrm{~Hz}, \mathrm{H}-1^{\prime \prime}\right)$ in the spectrum were indicative of a dimethylchromene ring. The angular fusion of the chromene ring at C- 8 was deduced from the low field shift of $\mathrm{H}-1 "\left(\delta_{\mathrm{H}} 8.02\right)$, which was located in the deshielding area of the carbonyl group. The ${ }^{1} \mathrm{H}$ and ${ }^{13} \mathrm{C}$ NMR spectroscopic data
(Table 1) were shown to be similar to those of the known xanthone, paxanthone B [13], except that the hydroxyl group at $\mathrm{C}-3$ of paxanthone $\mathrm{B}$ was replaced by a methoxy group. In the HMBC correlations of 1 (Fig. 2), the methoxy proton at $\delta_{\mathrm{H}} 3.89$ showed a cross-peak with $\delta_{\mathrm{C}} 163.5$ (C-3). In addition, a methine proton at $\delta_{\mathrm{H}} 8.02$ showed cross-peaks with $\delta_{\mathrm{C}} 77.1\left(\mathrm{C}-3{ }^{\prime \prime}\right), 108.5(\mathrm{C}-8 \mathrm{a})$, and 136.9 (C-7), confirming that a dimethylchromene ring was located at $\mathrm{C}-8$, and a methylene proton at $\delta_{\mathrm{H}} 3.44$ showed cross-peaks with $\delta_{\mathrm{C}} 131.7\left(\mathrm{C}-3{ }^{\prime}\right), 153.7(\mathrm{C}-4 \mathrm{a})$, and $163.5(\mathrm{C}-3)$, indicating that a prenyl group was attached to $\mathrm{C}-4$. Thus, the complete assignment of schomburgone A was determined as $\mathbf{1}$.

Schomburgone B (2) was obtained as yellow oil. Its molecular formula was determined as $\mathrm{C}_{19} \mathrm{H}_{18} \mathrm{O}_{5}$ by the negative HRESIMS measurement through the ion peak at $m / z 325.1098[\mathrm{M}-\mathrm{H}]^{+}$(calcd. for $\mathrm{C}_{19} \mathrm{H}_{17} \mathrm{O}_{5}, 325.1076$ ). The 
Table 1 NMR spectroscopic data (400 MHz, $\mathrm{CDCl}_{3}$ ) for $\mathbf{1}$ and $\mathbf{2}$

\begin{tabular}{|c|c|c|c|c|}
\hline \multirow[t]{2}{*}{ Position } & \multicolumn{2}{|l|}{1} & \multicolumn{2}{|l|}{2} \\
\hline & $\delta_{\mathrm{H}}(J$ in $\mathrm{Hz})$ & $\delta_{\mathrm{C}}$ & $\delta_{\mathrm{H}}(\mathrm{J}$ in $\mathrm{Hz})$ & $\delta_{\mathrm{C}}$ \\
\hline 1 & & 162.0 & & 163.0 \\
\hline 2 & $6.33(\mathrm{~s})$ & 94.1 & $6.43(\mathrm{~s})$ & 96.2 \\
\hline 3 & & 163.5 & & 166.1 \\
\hline 4 & & 107.2 & & 113.9 \\
\hline $4 a$ & & 153.7 & & 154.0 \\
\hline 5 & $6.85(\mathrm{~s})$ & 102.6 & & 145.9 \\
\hline 6 & & 151.1 & $7.26(\mathrm{~d}, 7.62)$ & 120.3 \\
\hline 7 & & 136.9 & $7.23(\mathrm{t}, 7.62)$ & 124.6 \\
\hline 8 & & 119.9 & $7.71(\mathrm{~d}, 7.62)$ & 116.6 \\
\hline $8 \mathrm{a}$ & & 108.5 & & 121.0 \\
\hline 9 & & 183.0 & & 182.0 \\
\hline $9 \mathrm{a}$ & & 103.9 & & 104.1 \\
\hline $10 \mathrm{a}$ & & 153.5 & & 144.8 \\
\hline $1^{\prime}$ & $3.44(\mathrm{~d}, 7.23)$ & 21.7 & & 42.0 \\
\hline $2^{\prime}$ & $5.20(\mathrm{t}, 7.23)$ & 122.4 & $6.70(\mathrm{dd}, 10.63,17.67)$ & 156.3 \\
\hline $3^{\prime}$ & & 131.7 & $\begin{array}{l}5.22(\mathrm{~d}, 17.67), 5.07(\mathrm{~d}, \\
10.63)\end{array}$ & 104.5 \\
\hline $4^{\prime}$ & $1.67(\mathrm{~s})$ & 25.9 & $1.61(\mathrm{~s})$ & 28.4 \\
\hline $5^{\prime}$ & $1.85(\mathrm{~s})$ & 18.0 & $1.61(\mathrm{~s})$ & 28.4 \\
\hline $1^{\prime \prime}$ & $8.02(\mathrm{~d}, 10.23)$ & 121.2 & & \\
\hline $2^{\prime \prime}$ & $5.83(\mathrm{~d}, 10.23)$ & 132.5 & & \\
\hline $3 "$ & & 77.1 & & \\
\hline $4^{\prime \prime}$ & $1.50(\mathrm{~s})$ & 27.5 & & \\
\hline $5 "$ & $1.50(\mathrm{~s})$ & 27.5 & & \\
\hline $1-\mathrm{OH}$ & $13.38(\mathrm{~s})$ & & $13.25(\mathrm{~s})$ & \\
\hline $5-\mathrm{OH}$ & & & $6.42(\mathrm{~s})$ & \\
\hline $6-\mathrm{OH}$ & $6.26(\mathrm{~s})$ & & & \\
\hline $3-\mathrm{OCH}_{3}$ & $3.89(\mathrm{~s})$ & 56.1 & $3.91(\mathrm{~s})$ & 56.2 \\
\hline
\end{tabular}
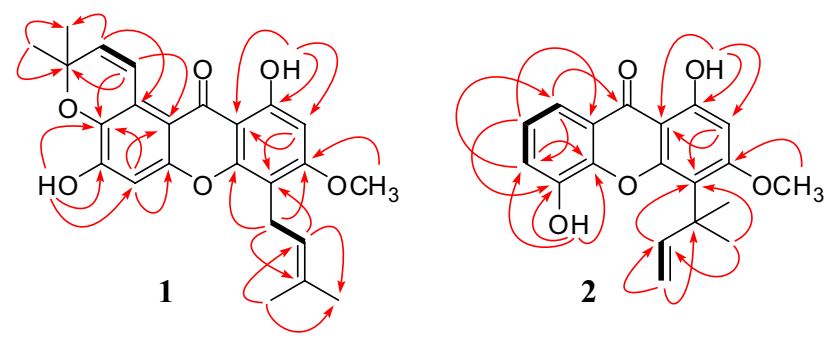

Fig. 2 Key HMBC (arrow curves) and COSY (bold lines) correlations of $\mathbf{1}$ and $\mathbf{2}$

UV spectrum displayed absorption bands at $\lambda_{\max } 394,315$ and $244 \mathrm{~nm}$. The IR spectrum showed phenolic hydroxyl groups and a hydrogen bonded carbonyl group at 3432 and $1642 \mathrm{~cm}^{-1}$. The ${ }^{1} \mathrm{H}$ NMR spectrum showed the presence of a 1,1-dimethylallyl group, which was confirmed by a singlets at $\delta_{\mathrm{H}} 1.61\left(6 \mathrm{H}, \mathrm{s}, \mathrm{H}-4^{\prime}\right.$ and $\left.\mathrm{H}-5^{\prime}\right)$ for two methyls, a doublet of doublet at $\delta_{\mathrm{H}} 6.70(1 \mathrm{H}, \mathrm{dd}, J=10.63 \mathrm{~Hz}, 17.67$,
$\mathrm{H}-2$ ) for the methine proton and two doublets at $\delta_{\mathrm{H}} 5.07$ $(1 \mathrm{H}, \mathrm{d}, J=10.63 \mathrm{~Hz}, \mathrm{H}-3)$ and $5.22(1 \mathrm{H}, \mathrm{d}, J=17.67 \mathrm{~Hz}$, $\mathrm{H}-3$ ') for the methylene protons. Moreover, the methoxy signal, hydroxyl signal, aromatic proton signal and hydrogen bonded hydroxyl signal appeared as four singlets at $\delta_{\mathrm{H}} 3.91$ $\left(3 \mathrm{H}, \mathrm{s}, \mathrm{OCH}_{3}-3\right), 6.42(1 \mathrm{H}, \mathrm{s}, \mathrm{OH}-5), 6.43(1 \mathrm{H}, \mathrm{s}, \mathrm{H}-2)$ and $13.25(1 \mathrm{H}, \mathrm{s}, \mathrm{OH}-1)$, respectively. The ABC-type aromatic protons were assigned at $\delta_{\mathrm{H}} 7.23(1 \mathrm{H}, \mathrm{t}, J=7.62 \mathrm{~Hz}, \mathrm{H}-7)$, $7.26(1 \mathrm{H}, \mathrm{d}, J=7.62 \mathrm{~Hz}, \mathrm{H}-6)$ and $7.71(1 \mathrm{H}, \mathrm{d}, J=7.62 \mathrm{~Hz}$, $\mathrm{H}-8$ ). The ${ }^{1} \mathrm{H}$ and ${ }^{13} \mathrm{C}$ NMR spectroscopic data (Table 1) were shown to be similar to those of the known xanthone, pancixanthone A [14], except that the hydroxyl group at C-3 of pancixanthone-A was substituted by a methoxy group. In the HMBC correlations of $\mathbf{2}$ (Fig. 2), the methoxy proton at $\delta_{\mathrm{H}} 3.91$ showed a cross-peak with $\delta_{\mathrm{C}} 166.1(\mathrm{C}-3)$. Moreover, two methyl protons at $\delta_{\mathrm{H}} 1.61$ showed cross-peaks with $\delta_{\mathrm{C}}$ $113.9(\mathrm{C}-4)$ and $156.3(\mathrm{C}-2)$, confirming that a 1,1-dimethylallyl group was connected at C-4. Thus, the completed assignment of schomburgone B was determined as $\mathbf{2}$.

In previous research many xanthones showed cytotoxicity [15]. Therefore, all isolated compounds were evaluated in vitro for their cytotoxicity against five cancer cell lines (KB, HeLa S-3, HT-29, MCF-7 and HepG-2) (Table 2). Compounds 3-6 and 8 showed good cytotoxicity against all five cancer cell lines with $\mathrm{IC}_{50}$ values in the range of 1.45-9.46 $\mu \mathrm{M}$. Compounds 1 and 7 showed weak cytotoxicity against all five cancer cell lines with $\mathrm{IC}_{50}$ values in the range of 34.69-73.10 $\mu \mathrm{M}$. Compounds $\mathbf{2 , 9}$ and $\mathbf{1 0}$ showed inactive cytotoxicity against all five cancer cell lines with $\mathrm{IC}_{50}$ values $>100 \mu \mathrm{M}$. The SAR studied data (Fig. 1; Table 2) of xanthones suggest that the ortho hydroxy group at C-5 and C-6 and the 1,1-dimethylallyl group at C-4 might improve the cytotoxicity as inferred from the comparison of their cytotoxicity of compounds $\mathbf{1}-\mathbf{1 0}$.

\section{Experimental}

\section{General experimental procedures}

NMR spectra were recorded on Bruker 400 AVANCE spectrometer. HRESIMS spectra were obtained using a Bruker MICROTOF model mass spectrometer. The UV-visible absorption spectra were recorded on a UV-2550 UV-Vis spectrometer (Shimadzu, Kyoto, Japan). The IR spectra were measured on a Nicolet 6700 FT-IR spectrometer using $\mathrm{KBr}$ discs.

\section{Plant material}

The bark of G. schomburgkiana was collected from Bang Ramat Road, Khwaeng Bang Ramat, Khet Taling Chan, Bangkok Thailand $\left(13^{\circ} 45^{\prime} 42^{\prime \prime} \mathrm{N}, 100^{\circ} 24^{\prime} 56^{\prime \prime} \mathrm{E}\right)$, in June 
Table 2 In vitro cytotoxicity of compounds 1-10 against five cancer cell lines

\begin{tabular}{lccccc}
\hline Compounds & $\mathrm{IC}_{50}(\mu \mathrm{M}) \pm \mathrm{SD}$ & & & \\
\cline { 2 - 6 } & $\mathrm{KB}$ & HeLa S-3 & HT-29 & MCF-7 & HepG-2 \\
\hline $\mathbf{1}$ & $45.05 \pm 2.08$ & $69.22 \pm 4.02$ & $61.92 \pm 2.40$ & $52.21 \pm 1.71$ & $73.19 \pm 1.14$ \\
$\mathbf{2}$ & $>100$ & $>100$ & $>100$ & $>100$ & $>100$ \\
$\mathbf{3}$ & $5.23 \pm 0.19$ & $7.95 \pm 0.25$ & $7.87 \pm 0.30$ & $6.70 \pm 0.81$ & $5.93 \pm 0.94$ \\
$\mathbf{4}$ & $4.69 \pm 0.21$ & $7.57 \pm 0.26$ & $9.18 \pm 0.38$ & $5.26 \pm 0.55$ & $4.89 \pm 0.83$ \\
$\mathbf{5}$ & $5.08 \pm 0.36$ & $5.82 \pm 0.15$ & $4.17 \pm 0.07$ & $7.19 \pm 0.36$ & $9.46 \pm 0.45$ \\
$\mathbf{6}$ & $4.30 \pm 0.12$ & $6.60 \pm 0.24$ & $5.92 \pm 0.40$ & $3.21 \pm 0.71$ & $3.19 \pm 0.14$ \\
$\mathbf{7}$ & $38.17 \pm 6.83$ & $65.26 \pm 3.89$ & $34.69 \pm 2.29$ & $46.03 \pm 1.29$ & $54.80 \pm 1.18$ \\
$\mathbf{8}$ & $1.45 \pm 0.09$ & $1.62 \pm 0.20$ & $1.87 \pm 0.30$ & $1.70 \pm 0.81$ & $1.93 \pm 0.94$ \\
$\mathbf{9}$ & $>100$ & $>100$ & $>100$ & $>100$ & $>100$ \\
$\mathbf{1 0}$ & 100 & $>100$ & $>100$ & $>100$ & $>100$ \\
Doxorubicin & $0.13 \pm 0.006$ & $0.03 \pm 0.001$ & $0.31 \pm 0.07$ & $0.42 \pm 0.14$ & $1.23 \pm 0.02$ \\
\hline
\end{tabular}

$\mathrm{IC}_{50} \leq 10=$ good activity, $10<\mathrm{IC}_{50} \leq 30=$ moderate activity, $\mathrm{IC}_{50}>100=$ inactive
2017. The plant material was identified by Dr. Suttira Sedlak, a botanist at the Walai Rukhavej Botanical Research Institute, Mahasarakham University, and a specimen retained as a reference (Khumkratok no. 92-08).

\section{Extraction and isolation}

The air-dried bark of $G$. schomburgkiana $(2.0 \mathrm{~kg}$ ) was extracted with $\mathrm{CH}_{2} \mathrm{Cl}_{2}$ at room temperature for 7 days $(2 \times 25 \mathrm{~L})$. The $\mathrm{CH}_{2} \mathrm{Cl}_{2}$ crude extract $(91.0 \mathrm{~g})$ was further separated by column chromatography (CC) over silica gel $\mathrm{CC}$ and eluted with a gradient of Hexane-EtOAc $(90,70$, 50 and $30 \%$ Hexane-EtOAc each $5 \mathrm{~L}$ ) to give six fractions (A-F). Fraction A (4.0 g) was purified by Sephadex LH-20 column eluted with $80 \% \mathrm{CH}_{2} \mathrm{Cl}_{2}-\mathrm{MeOH}(2 \mathrm{~L})$ and further applied to a radial chromatography (chromatotron) with $95 \%$ hexane-EtOAc (200 mL) to afford compound 9 (3.2 mg). Fraction B (10.5 g) was purified by Sephadex LH-20 column eluted with $80 \% \mathrm{CH}_{2} \mathrm{Cl}_{2}-\mathrm{MeOH}(2 \mathrm{~L})$ and further applied to a chromatotron with $50 \%$ hexane- $\mathrm{CH}_{2} \mathrm{Cl}_{2}(200 \mathrm{~mL})$ to obtain compounds 2 (4.2 mg), 4 (2.5 mg) and 7 (2.3 mg). Compound 1 (7.2 mg) was separated by Sephadex LH-20 column eluted with $50 \% \mathrm{CH}_{2} \mathrm{Cl}_{2}-\mathrm{MeOH}(2 \mathrm{~L})$ from fraction C (2.0 g). Fraction D (6.5 g) was purified by Sephadex $\mathrm{LH}-20$ column eluted with $50 \% \mathrm{CH}_{2} \mathrm{Cl}_{2}-\mathrm{MeOH}(2 \mathrm{~L})$ to give compounds $5(8.5 \mathrm{mg})$ and $8(4.6 \mathrm{mg})$. Fraction $\mathrm{E}(8.5 \mathrm{~g})$ was purified by Sephadex LH-20 column eluted with $50 \%$ $\mathrm{CH}_{2} \mathrm{Cl}_{2}-\mathrm{MeOH}(2 \mathrm{~L})$ and further applied to a chromatotron with $70 \%$ hexane-EtOAc $(200 \mathrm{~mL})$ to obtain compounds $\mathbf{3}(5.2 \mathrm{mg})$ and $\mathbf{1 0}(5.5 \mathrm{mg})$. Finally, fraction F (1.2 g) was subjected to silica gel $\mathrm{CC}$ eluted with $100 \% \mathrm{CH}_{2} \mathrm{Cl}_{2}$ and further purified by Sephadex LH-20 column eluted with $80 \%$ $\mathrm{CH}_{2} \mathrm{Cl}_{2}-\mathrm{MeOH}(2 \mathrm{~L})$ to yield compound 6 (6.5 mg).

Schomburgone $A$ (1): yellow oil; $\mathrm{UV}\left(\mathrm{CHCl}_{3}\right) \lambda_{\text {max }}(\log$ ع): 395 (3.6), 315 (4.2) and 243 (4.4) nm,. IR $\nu_{\max }(\mathrm{KBr})$ : 3422 and $1632 \mathrm{~cm}^{-1}$; ${ }^{1} \mathrm{H}\left(400 \mathrm{MHz}, \mathrm{CDCl}_{3}\right)$ and ${ }^{13} \mathrm{C}$
NMR (100 MHz, $\mathrm{CDCl}_{3}$ ) spectroscopic data, see Table 1; HRESIMS $m / z 407.1527[\mathrm{M}-\mathrm{H}]^{+}$(calcd. for $\mathrm{C}_{24} \mathrm{H}_{23} \mathrm{O}_{6}$, 407.1495).

Schomburgone B (2): yellow oil; UV $\left(\mathrm{CHCl}_{3}\right) \lambda_{\text {max }}(\log$ $\varepsilon): 394$ (3.5), 315 (4.0) and 244 (4.2) nm,. IR $\nu_{\max }(\mathrm{KBr})$ : 3432 and $1642 \mathrm{~cm}^{-1}$; ${ }^{1} \mathrm{H}\left(400 \mathrm{MHz}, \mathrm{CDCl}_{3}\right)$ and ${ }^{13} \mathrm{C}$ NMR (100 MHz, $\mathrm{CDCl}_{3}$ ) spectroscopic data, see Table 1; HRESIMS $m / z, 325.1098[\mathrm{M}-\mathrm{H}]^{+}$(calcd. for $\mathrm{C}_{19} \mathrm{H}_{17} \mathrm{O}_{5}$, 325.1076).

\section{Cytotoxicity assay}

All isolated compounds (1-10) were subjected to cytotoxic evaluation against KB (human epidermoid carcinoma), HeLa S-3 (human cervical carcinoma), HT-29 (human colon adenocarcinoma), MCF-7 (human breast adenocarcinoma) and HepG-2 (human liver carcinoma) cell lines employing the colorimetric method [16]. Doxorubicin was used as the reference substance which exhibits activity against five cancer cell lines. The 3-(4,5-dimethylthiazol-2-yl)-2,5-diphenyl-tetrazolium bromide (Sigma Chemical Co., USA) was dissolved in saline to make a $5 \mathrm{mg} / \mathrm{mL}$ stock solution. Cancer cells $\left(3 \times 10^{3}\right.$ cells $)$ suspended in $100 \mu \mathrm{g} /$ wells of MEM medium containing 10\% fetal calf serum (Gibco BRL, Life Technologies, NY, USA) were seeded onto a 96-well culture plate (Costar, Corning Incorporated, NY, USA). After $24 \mathrm{~h}$ pre-incubation at $37{ }^{\circ} \mathrm{C}$ in a humidified atmosphere of $5 \%$ $\mathrm{CO}_{2} / 95 \%$ air to allow cellular attachment, various concentrations of test solution $(0.1,0.3,1.0,3.0,10.0,30.0$, and $100.0 \mu \mathrm{M}$, each $10 \mu \mathrm{L} /$ well) were added and these were then incubated for $48 \mathrm{~h}$ under the above conditions. At the end of the incubation, $10 \mu \mathrm{L}$ of tetrazolium reagent was added into each well followed by further incubation at $37^{\circ} \mathrm{C}$ for $4 \mathrm{~h}$. The supernatant was decanted, and DMSO $(100 \mu \mathrm{L} /$ well) was added to allow formosan solubilization. The optical density of each well was detected using a Microplate 
reader at $550 \mathrm{~nm}$ and for correction at $595 \mathrm{~nm}$. Each determination represented the average mean of six replicates. The $50 \%$ inhibition concentration $\left(\mathrm{IC}_{50}\right.$ value) was determined by curve fitting.

Acknowledgments The authors are grateful to the Graduate School of Chulalongkorn University for a Postdoctoral Fellowship (Ratchadaphiseksomphot Endowment Fund) to SK. We also thank Dr. Suttira Sedlak, Walai Rukhavej Botanical Research Institute, Mahasarakham University, Mahasarakham 44000, Thailand for identification and deposition of the plant material.

Open Access This article is distributed under the terms of the Creative Commons Attribution 4.0 International License (http://creativeco mmons.org/licenses/by/4.0/), which permits unrestricted use, distribution, and reproduction in any medium, provided you give appropriate credit to the original author(s) and the source, provide a link to the Creative Commons license, and indicate if changes were made.

\section{References}

1. Mungmee C, Sitthigool S, Suttisri R, Buakeaw A (2012) Xanthones and biphenyls from Garcinia schomburgkiana wood and their cytotoxicity. Thai J Pharm Sci 36:6-9

2. Le DH, Nishimura K, Takenaka Y, Mizushina Y, Tanahashi T (2016) Polyprenylated Benzoylphloroglucinols with DNA polymerase inhibitory activity from the fruits of Garcinia schomburgkiana. J Nat Prod 79:1798-1807

3. Sukandar ER, Siripong P, Khumkratok S, Tip-Pyang S (2016) New depsidones and xanthone from the roots of Garcinia schomburgkiana. Fitoterapia 111:73-77

4. Kobayashi M, Mahmud T, Yoshioka N, Shibuya H, Kitagawa I (1997) Indonesian medicinal plants. XXI. Inhibitors of $\mathrm{Na}^{+} / \mathrm{H}^{+}$ exchanger from the bark of Erythrina variegata and the roots of Maclura cochinchinensis. Chem Pharm Bull 45:1615-1619

5. Chang CH, Lin CC, Kawata Y, Hattori M, Namba T (1989) Prenylated xanthones from Cudrania cochinchinensis. Phytochemistry $28: 2823-2826$
6. Rukachaisirikul V, Ritthiwigrom T, Pinsa A, Sawangchote P, Taylor WC (2003) Xanthones from the stem bark of Garcinia nigrolineata. Phytochemistry 64:1149-1156

7. Helboe P, Arends P (1973) Xanthone studies. VI. Synthesis of jacareubin, isojacareubin, and some hydroxyxanthones with allylic substituents. Arch Pharm Chemi Sci Ed 1:549-555

8. Ito C, Miyamoto Y, Nakayama M, Kawai Y, Rao KS, Furukawa H (1997) A novel depsidone and some new xanthones from Garcinia species. Chem Pharm Bull 45:1403-1413

9. Wolfrom ML, Komitsky FJ, Fraenkel G, Looker JH, Dickey EE, McWain P (1963) Macluraxanthone and two accompanying pigments from the root bark of the osage orange. Tetrahedron Lett 4:749-755

10. Delle Monache F, Ferrari F, Marini-Bettolo GB, Maxfield P, Cerrini S, Fedeli W (1979) Vismiones from Vismia baccifera var. dealdata (H. B. K.): chemistry and X-ray structure determination. Gazz Chim Ital 109:301-310

11. Botta B, Delle Monache F, Delle Monache G, Marini Bettolo GB, Oguakwa JU (1983) 3-Geranyloxy-6-methyl-1,8-dihydroxyanthraquinone and vismiones $\mathrm{C}, \mathrm{D}$, and $\mathrm{E}$, from Psorospermum febrifugum. Phytochemistry 22:539-542

12. Kaennakam S, Siripong P, Tip-Pyang S (2015) Kaennacowanols A-C, three new xanthones and their cytotoxicity from the roots of Garcinia cowa. Fitoterapia 102:171-176

13. Ishiguro K, Nakajima M, Fukumoto H, Isoi K (1995) Co-occurrence of prenylated xanthones and their cyclization products in cell suspension cultures of Hypericum patulum. Phytochemistry 38:867-869

14. Ito C, Miyamoto Y, Rao KS, Furukawa H (1996) A novel dibenzofuran and two new xanthones from Calophyllum panciflorum. Chem Pharm Bull 44:441-443

15. Vo HT, Nguyen NTT, Nguyen HT, Do KQ, Connolly JD, Maas $\mathrm{G}$ (2012) Cytotoxic tetraoxygenated xanthones from the bark of Garcinia schomburgkiana. Phytochem Lett 5:553-557

16. Kongkathip N, Kongkathip B, Siripong P, Sangma C, Luangkamin S, Niyomdecha M (2003) Potent antitumor activity of synthetic 1,2-naphthoquinones and 1,4-naphthoquinones. Bioorganic Med Chem 11:3179-3191 